\title{
Impacts of a newly identified behaviour-altering trematode on its host amphipod: from the level of gene expression to population
}

\author{
YASMIN GULER ${ }^{1}$, STEPHEN SHORT ${ }^{1}$, AMAIA GREEN ETXABE ${ }^{1}$, CHRISTOPHER \\ M. SHERHOD ${ }^{1}$, PETER KILLE ${ }^{2}$ and ALEX T. FORD ${ }^{1} *$ \\ ${ }^{1}$ Institute of Marine Sciences, School of Biological Sciences, University of Portsmouth, Ferry Road, Portsmouth, \\ Hampshire , PO4 9LY, UK \\ ${ }^{2}$ Cardiff School of Biosciences, Biological Sciences Building, Museum Avenue, Cardiff, CF10 3AT, UK
}

(Received 23 Fanuary 2015; revised 19 May 2015; accepted 19 May 2015; first published online 18 August 2015)

\begin{abstract}
SUMMARY
Changes to host behaviour induced by some trematode species, as a means of increased trophic transmission, represents one of the seminal examples of host manipulation by a parasite. The amphipod Echinogammarus marinus (Leach, 1815) is infected with a previously undescribed parasite, with infected individuals displaying positive phototaxic and negative geotaxic behaviour. This study reveals that the unknown parasite encysts in the brain, nerve cord and the body cavity of E. marinus, and belongs to the Microphallidae family. An 18 month population study revealed that host abundance significantly and negatively correlated with parasite prevalence. Investigation of the trematode's influence at the transcriptomic level revealed genes with putative neurological functions, such as serotonin receptor $1 \mathrm{~A}$, an inebriated-like neurotransmitter, tryptophan hydroxylase and amino acid decarboxylase, present consistent altered expression in infected animals. Therefore, this study provides one of the first transcriptomic insights into the neuronal gene pathways altered in amphipods infected with a trematode parasite associated with changes to its host's behaviour and population structure.
\end{abstract}

Key words: parasitic-manipulation, host behaviour, neurological genes, serotonin, amphipods.

\section{INTRODUCTION}

Certain parasite species are known to induce changes to host behaviour as a means of increased trophic transmission, a process that represents one of the seminal examples of parasite-induced behavioural manipulation (Pearson, 1972; Bethel and Holmes, 1973; Camp and Huizinga, 1979; Helluy, 1983a, b; Combes, 1991; Combes et al. 1994; Haas, 1994; Esch et al. 2002; Mouritsen and Poulin, 2002). Among intertidal animals, trematodes are one of the most common metazoan parasites (Mouritsen and Poulin, 2002) and consist of an estimated 25000 species, many of which are yet to be described (Esch et al. 2002). Trematodes are obligate parasites that have complex life cycles, infecting up to four hosts, taking many distinct forms and infecting their hosts in a variety of ways (Esch et al. 2002); with amphipod crustaceans generally often acting as second intermediate hosts (Pearson, 1972). It is known that for some trematode species, the metacercarial stage is capable of manipulating its intermediate host's behaviour to increase its chance of trophic transmission to the definitive host (Helluy, 1983a, b; Combes et al. 1994; Haas, 1994; Esch et al. 2002; Mouritsen and Poulin, 2002).

* Corresponding author. Institute of Marine Sciences, School of Biological Sciences, University of Portsmouth, Ferry Road, Portsmouth, Hampshire, PO4 9LY, UK. E-mail: alex.ford@port.ac.uk
The widespread marine amphipod Echinogammarus marinus has been used to understand strategies employed by a diverse range of parasites capable of manipulating the reproductive biology of its host (Short et al. 2012). However, the discovery that E. marinus can also be infected with a parasite apparently capable of manipulating host behaviour (Guler and Ford, 2010) has never been further investigated. In this case, infected specimens of the normally evasive $E$. marinus were found to spend significantly more time in the light and higher in the water column than uninfected individuals, a behaviour consistent with a parasitic strategy to increase trophic transmission. Such manipulative parasites are not unknown in amphipods, as the behaviour of infected E. marinus is similar to that observed in Gammarus insensibilis infected by the trematode Microphallus papillorobustus (Helluy, $1983 a, b)$. It has been suggested that such parasites alter host behaviour by influencing pathways in a similar manner to neuropharmcological methods. For example, it appears that biogenic amines are frequently targeted by behaviour manipulating parasites (Nolan, 1998; Pryon and Elizee, 2000; Klein, 2003; Adamo, 2013; Helluy, 2013). Furthermore, components of the serotonin pathway have been implicated by experiments demonstrating that injection of serotonin, a monoamine neurotransmitter, into gammarids causesbehaviours similar to that induced by manipulating parasites (Helluy and Holmes, 1990; Tain et al. 2006; 
Perrot-Minnot et al. 2014), while other neurotransmitters at similar concentrations, failed to induce a comparable response (Helluy and Holmes, 1990). In addition, it has been shown that once $M$. papillorobustus metacercariae encyst in the cerebral ganglia, specifically the protocerebrum responsible for all visual sensory input (Thomas et al. 2000; Helluy and Thomas, 2003; Kostadinova and Mavrodieva, 2005), serotonin levels become altered in specific regions, with a decrease of $62 \%$ observed in the optic neuropils (Ponton et al. 2006), a decrease thought to be due to the degeneration of discrete sets of serotonergic neurons. Consistent with studies implicating serotonin related pathways, positive phototaxic and negative geotaxic behavioural changes have been observed in E. marinus exposed to serotonin and the selective serotonin reuptake inhibitor (SSRI) fluoxetine (Guler and Ford, 2010). Uncovering the neurological pathways modulated by cerebral encysting behaviour-manipulating parasites promises to reveal profound insights into arthropod neurobiology (Poulin and Mouritsen, 2006; Shaw et al. 2009; Helluy and Thomas, 2010) and although our understanding of the molecular host-parasite interactions are still limited (Biron and Loxdale, 2013), the existing investigations make it possible to credibly hypothesize which molecular pathways are altered in infected $E$. marinus. This opens the possibility of using the available E. marinus genomic resources (Short et al. 2014) to investigate the molecular biology underlying parasite-induced behavioural-manipulation at a transcriptomic level.

This study aims to identify the parasite species infecting E. marinus by comparing the parasite ribosomal RNA gene sequences with sequences deposited in public databases and those isolated from $M$. papillorobustus. Secondly, this study investigates the potential impact of the $E$. marinus parasite at the population level by comparing parasite prevalence with host abundance. Finally, we investigate the molecular pathways being altered in infected animals by attempting to identify expression changes in genes with plausible links to neurological pathways.

\section{MATERIAL AND METHODS}

\section{Trematode harvesting and DNA isolation}

Echinogammarus marinus were collected from beneath seaweed in the intertidal zone during low tide. Infected $E$. marinus individuals were taken from Langstone Harbour, Portsmouth, UK $\left(50^{\circ} 47^{\prime} 23 \cdot 13 \mathrm{~N}\right.$ $\left.1^{\circ} 02^{\prime} 37 \cdot 25 \mathrm{~W}\right)$. Sixty adult males and females $(n=$ 120) were collected during June and July 2011 and the location of the trematode metacercaria were recorded within the body cavity and head. Gammarus insensibilis infected by $M$. papillorobustus were collected from Étang de Thau, France $\left(43^{\circ} 25^{\prime} \mathrm{N}, 3^{\circ} 35^{\prime}\right.$ E) and were kindly donated by Dr Frédéric Thomas (National Center of Scientific Research (CNRS) in
Montpellier, France). Twenty cysts from each amphipod population were stored in $70 \%$ ethanol at $-80{ }^{\circ} \mathrm{C}$. DNA was extracted using the DNAeasy kit (Qiagen, UK) following the manufacturers' protocol and quantified using a spectrophotometer (NanoDrop 1000).

\section{Amplification of trematode ribosomal RNA genes}

Primers were used to amplify the $18 \mathrm{~S}$ (537F, 1133R, $1073 \mathrm{~F}, 18 \mathrm{SR}, 18 \mathrm{SF}$ and 549R) (Near et al. 1998) and 28S (LSU-5, 1500R) (Olson et al. 2003) ribosomal RNA genes. Primers (PITSF, PITSR, Table 1) used to amplify the Internal Transcribed Spacer (ITS) region were designed using the $3^{\prime}$ end of the sequenced $18 \mathrm{~S}$ region and the $5^{\prime}$ end of the $28 \mathrm{~S}$ region. All primers were synthesized by Eurofins MWG Operon, Germany. Polymerase chain reaction (PCR) reactions were performed in $25 \mu \mathrm{L}$ reactions containing $1 \cdot 25$ mM $\mathrm{MgCl}_{2}, 1 \times$ PCR Buffer, $0.2 \mathrm{~mm}$ of each dNTP, $0.25 \mathrm{~mm}$ of each primer, $1 \mathrm{U}$ Taq DNA polymerase (Promega, UK), $10 \mathrm{ng}$ of genomic DNA. Reactions were carried out using the following thermal cycling conditions: $94{ }^{\circ} \mathrm{C}$ for 4 min followed by 32 cycles of $94{ }^{\circ} \mathrm{C}(45 \mathrm{~s}), 59^{\circ} \mathrm{C}(45 \mathrm{~s})$ and $72^{\circ} \mathrm{C}(1.5 \mathrm{~min})$, and a final incubation of $5 \mathrm{~min}$ at $72{ }^{\circ} \mathrm{C}$. PCR products were analysed by agarose gel electrophoresis and were eluted and purified using the QIAquick Gel Extraction and purification Kit (Qiagen, UK) following the manufacturer's protocol. The purified PCR products were subsequently sequenced by Source Bioscience, UK.

\section{Phylogenetic analysis}

The isolated parasite ribosomal sequences were used to perform a basic local alignment search tool (BLAST) analysis against the non-redundant sequences deposited in GenBank National Center for Biotechnology Information (NCBI, http://www.ncbi. nlm.nlh.gov) to reveal closely related sequences. The sequences obtained were aligned multiple sequence comparison by log-expectation (MUSCLE) and trimmed, before a phylogenetic tree was constructed using the maximum likelihood method implemented by the MEGA (v5·0) program (Hall, 2013).

Population sampling. Echinogammarus marinus were collected from Langstone Harbour, Portsmouth, UK $\left(50^{\circ} 47^{\prime} 23 \cdot 13 \mathrm{~N} 1^{\circ} 02^{\prime} 37 \cdot 25 \mathrm{~W}\right)$ during low tide by selecting five $1 \mathrm{~m}^{2}$ quadrats (total area $=5 \mathrm{~m}^{2}$ ) in the intertidal zone each month over an 18 month period (January 2010-June 2011). All algae and surface sediment (approximately $2 \mathrm{~cm}$ in depth) was retrieved and stored in polythene bags. In the laboratory, samples were washed and decanted through a $0.7 \mathrm{~mm}$ sieve and all algae were scraped to ensure all $E$. marinus individuals were collected. Individuals were separated into males, females and juveniles, and counted to assess relative abundances. To allow for 
Table 1. Primers designed using Primer-3 software [65] and synthesized by Eurofins MWG Operon

\begin{tabular}{ll}
\hline \hline Primer name & Sequence 5' end to $3^{\prime}$ \\
\hline PITSF & GTTTCGACTGCTCGAGTGGTG \\
PITSR & AACAACCTGAACACCACATTG \\
RHOD1F & CCCGCCAACATGCTGCCTGA \\
RHOD1R & CGGGTGACCGCAGGCTCTTG \\
RHOD2F & CGCGGTGTCCACCAACCCAT \\
RHOD2R & ATTGGCGGGTGATCGCAGGC \\
Ine1F & CGTGGAGGAGCCGTTGCCTG \\
Ine1R & CCTGTGCGGCATCCCTCTGC \\
Ine2F & CCGGAGGGCAATCTTGCCGG \\
Ine2R & CGAGACGAAGCTGGGCCGTC \\
ATFF & AACTGGCGATGGCTTGGGCG \\
ATFR & CCGAACCATGTGGGATCGGCC \\
Ty1F & GCGCGGTCTGAAATGCAGCC \\
Ty1R & GCTCCGTTTGGCCGGCTATGA \\
ADF & TAGCGGAGGCTGCGTCTGGT \\
ADR & TATCAATGCGTCCGGGCGGC \\
PHF & GGTCAAGACCTGGAGCGCGG \\
PHR & GGTGCTGTGGAACACGCGGA \\
$5 H T 1 F$ & CAACGCAGAGTACGGGGTTGGT \\
5HT1R & GCAAAACGGCGAAATCGAACGGG \\
AKF & GGAGGCTTAAGCAGTCA \\
AKR & GACGGGTTTTTGCCAAAGT \\
\hline \hline
\end{tabular}

later assessment of parasite prevalence and seasonality, 20 adults of each sex were selected from each monthly sample and stored in $70 \%$ ethanol at $-80{ }^{\circ} \mathrm{C}$.

PCR parasite screen. The DNA was isolated from the 20 adults of each sex set aside following the monthly sampling. The gonads and muscle tissue were dissected from the animal and washed with distilled water. DNA was extracted using the CHELEX $^{\odot}$ DNA extraction followed by a phenolchloroform step and ethanol precipitation. Extracted DNA was quantified using a spectrophotometer (NanoDrop 1000). The samples were screened for evidence of infection using PCR. All PCR reactions were performed in $25 \mu \mathrm{L}$ reactions containing $2.5 \mathrm{~mm}$ $\mathrm{MgCl}_{2}, \quad 0.25 \mathrm{~mm}$ of each dNTP, $0.5 \mathrm{~mm}$ of each primer (18SF 5-GATTAAGCCATGCATG CGTAAG-3 and Trem18SR1 5-GCCGCGG TAATTCCAGCTC-3), 1x PCR buffer, $1 \mathrm{U}$ Taq DNA polymerase (Promega, UK) and $10 \mathrm{ng}$ of template DNA. Reactions were carried out using the following thermal cycling conditions: $94{ }^{\circ} \mathrm{C}$ for $4 \mathrm{~min}$ followed by 32 cycles of $94{ }^{\circ} \mathrm{C}(45 \mathrm{~s}), 59^{\circ} \mathrm{C}(45 \mathrm{~s})$ and $72{ }^{\circ} \mathrm{C}(1.5 \mathrm{~min})$, and a final incubation of $5 \mathrm{~min}$ at 72 ${ }^{\circ} \mathrm{C}$. To check the quality of all DNA samples, amplification of the Glyceraldehyde 3-phosphate dehydrogenase (GAPDH) gene was performed (Yang et al. 2011). PCR product size was visualized on a $1 \cdot 2 \%$ agarose gel under a UV transilluminator following electrophoresis.

\section{Statistical analysis}

Relationships between two biological parameters, such as host abundance and parasite prevalence, were statistically analysed using Pearson's correlation coefficients. Relationships between parasite prevalence and environmental parameters were conducted using regression analysis performed with a statistical

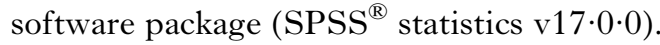

\section{Candidate gene selection and primer development}

Genes with functional links to neurological and serotonin pathways in Drosophilia melanogaster were retrieved from FlyBase (flybase.org) and were used to perform a local BLAST search against the $E$. marinus transcriptome database (Short et al. 2014). Sequences sharing a high level of sequence identity $(E$-value $\leqslant 1 \mathrm{E}-5)$ were taken and additional BLAST analyses (BLASTn) were performed against GenBank sequences (NCBI) to confirm the annotation. Gene candidates were selected on the basis of their direct involvement in the serotonin pathway or within processes that might plausibly influence behavioural responses in E. marinus (see Table 2). The only exception to this was a predicted Arginine Kinase, chosen due to its involvement in a specific immune response induced by the behaviourmanipulating trematode $M$. papillorobustus (Ponton et al. 2006). Primers were designed (Rozen and Skaletsky, 2000) against the selected E. marinus contiguous sequence (Table 1) and synthesized by Eurofins MWG Operon, Germany. All primers were tested for their quantitative real-time PCR (qPCR) suitability using PCR carried out in $25 \mu \mathrm{L}$ volume containing $1.5 \mathrm{mM} \mathrm{MgCl}_{2}, 1 \mathrm{x}$ PCR buffer, $0.25 \mathrm{~mm}$ each dNTP, $1 \mathrm{U}$ Taq DNA polymerase (Promega GoTaq ${ }^{\circledR}$ ) and $10 \mathrm{ng}$ cDNA (see section 
Table 2. Identifying Echinogammarus marimus genes with putative neurological roles. Drosopholia genes with functional links to serotonin and neurological pathways were used to BLAST search the E. marinus transcriptome database to identify orthologous sequences. The retrieved E. marinus sequences were then compared with annotated sequences in GenBank (NCBI) database to confirm the putative annotation

\begin{tabular}{|c|c|c|c|c|c|c|c|c|}
\hline Primer & $\begin{array}{l}\text { Primer } \\
\text { name }\end{array}$ & Sequence $5^{\prime}$ end to $3^{\prime}$ & Target Gene & GenBank ID & Ref. species & $\begin{array}{l}\text { Query } \\
\text { Coverage (\%) }\end{array}$ & $\begin{array}{l}\text { Max } \\
\text { identity (\%) }\end{array}$ & $E$-value \\
\hline 1 & $\begin{array}{l}\text { Ine1 } \mathrm{F} \\
\text { Ine1 } \mathrm{R}\end{array}$ & $\begin{array}{l}\text { CGTGGAGGAGCCGTTGCCTG } \\
\text { CCTGTGCGGCATCCCTCTGC }\end{array}$ & Neurotransmitter & NM057664.5 & $\begin{array}{l}\text { Culex } \\
\text { quinquefasciatus }\end{array}$ & 37 & 74 & $4 \cdot 00 \mathrm{E}-05$ \\
\hline 2 & $\begin{array}{l}\text { Ine2F } \\
\text { Ine2R }\end{array}$ & $\begin{array}{l}\text { CCGGAGGGCAATCTTGCCGG } \\
\text { CGAGACGAAGCTGGGCCGTC }\end{array}$ & Inebriated neurotransmitter & NM_001169400·1 & $\begin{array}{l}\text { Drosophila } \\
\text { melanogaster }\end{array}$ & 79 & 70 & $8 \cdot 00 \mathrm{E}-09$ \\
\hline 3 & $\begin{array}{l}\text { RHOD1F } \\
\text { RHOD1R }\end{array}$ & $\begin{array}{l}\text { CCCGCCAACATGCTGCCTGA } \\
\text { CGGGTGACCGCAGGCTCTTG }\end{array}$ & Rhodopsin & DQ852593.1 & $\begin{array}{l}\text { Neomysis } \\
\text { americana }\end{array}$ & 67 & 74 & $4 \cdot 00 \mathrm{E}-74$ \\
\hline 4 & $\begin{array}{l}\text { RHOD2F } \\
\text { RHOD2R }\end{array}$ & $\begin{array}{l}\text { CGCGGTGTCCACCAACCCAT } \\
\text { ATTGGCGGGTGATCGCAGGC }\end{array}$ & Rhodopsin & НМ044848·1 & $\begin{array}{l}\text { Lysiosquillina } \\
\text { maculata }\end{array}$ & 62 & 75 & $6 \cdot 00 \mathrm{E}-98$ \\
\hline 5 & $\begin{array}{l}\text { ATFF } \\
\text { ATFR }\end{array}$ & $\begin{array}{l}\text { AACTGGCGATGGCTTGGGCG } \\
\text { CCGAACCATGTGGGATCGGCC }\end{array}$ & $\begin{array}{l}\text { Nutrient Amino acid } \\
\text { transporter }\end{array}$ & NM_131991·2 & $\begin{array}{l}\text { Drosophila } \\
\text { melanogaster }\end{array}$ & 31 & 75 & $2 \cdot 00 \mathrm{E}-21$ \\
\hline 6 & $\begin{array}{l}\text { Ty3F } \\
\text { Ty3R }\end{array}$ & $\begin{array}{l}\text { GCGCGGTCTGAAATGCAGCC } \\
\text { GCTCCGTTTGGCCGGCTATGA }\end{array}$ & $\begin{array}{l}\text { Trytophan } 5 \text {-monooxygen- } \\
\text { ase activation protein }\end{array}$ & NM_013011·3 & Rattus norvegicus & 82 & 71 & $2 \cdot 00 \mathrm{E}-35$ \\
\hline 7 & $\begin{array}{l}\mathrm{ADF} \\
\mathrm{ADR}\end{array}$ & $\begin{array}{l}\text { TAGCGGAGGCTGCGTCTGGT } \\
\text { TATCAATGCGTCCGGGCGGC }\end{array}$ & Amino acid decarboxylase & XM002403644·1 & Ixodes scapularis & 57 & 79 & $2 \cdot 00 \mathrm{E}-34$ \\
\hline 8 & $\begin{array}{l}\text { PHF } \\
\text { PHR }\end{array}$ & $\begin{array}{l}\text { GGTCAAGACCTGGAGCGCGG } \\
\text { GGTGCTGTGGAACACGCGGA }\end{array}$ & Trytophan hydroxylase & AY099427·1 & Aedes aegypti & 49 & 72 & $6 \cdot 00 \mathrm{E}-142$ \\
\hline 9 & $5 \mathrm{HT} 1 \mathrm{~F}$ & CAACGCAGAGTACGGGGTTGGT & Serotonin receptor 1 & NM_057454·3 & $\begin{array}{l}\text { Drosophila } \\
\text { melanogaster }\end{array}$ & \multicolumn{3}{|c|}{$\begin{array}{l}\text { No sequence found primers designed } \\
\text { directly from sequence }\end{array}$} \\
\hline 10 & $\begin{array}{l}5 \mathrm{HT} 1 \mathrm{R} \\
\text { AKF } \\
\text { AKR }\end{array}$ & $\begin{array}{l}\text { GCAAAACGGCGAAATCGAACGGG } \\
\text { GGAGGCTTAAGCAGTCA } \\
\text { GACGGGTTTTTGCCAAAGT }\end{array}$ & Arginine Kinase & GQ246164·1 & Penaeus monodon & 38 & 86 & $0 \cdot 0 \mathrm{E}$ \\
\hline
\end{tabular}


PCR parasite screen). A primer concentration $10 \mathrm{mM}$ was determined to be suitable for all primers except ine 1, 2 and $5-H T_{1 A}$, the concentrations were reduced to $5 \mathrm{~mm}$ to eliminate primer-dimer formation. Reactions were carried out using the following thermal cycling conditions: $95^{\circ} \mathrm{C}(4 \mathrm{~min})$ followed by 35 cycles of $95^{\circ} \mathrm{C}(30 \mathrm{~s}), 60^{\circ} \mathrm{C}(45 \mathrm{~s}), 72^{\circ} \mathrm{C}(45$ s) with a final incubation of $5 \mathrm{~min}$ at $72^{\circ} \mathrm{C}$. PCR products were analysed by agarose-gel electrophoresis to establish primer specificity.

\section{$R N A$ isolation and $c D N A$ synthesis}

The heads were removed from the bodies of infected and uninfected males ( $n=18$ in each group), before the first pereon and antennae were amputated. Heads were immediately snap frozen using liquid nitrogen following dissection and crushed in TRI Reagent ${ }^{\circledR}$ (Ambion, UK). The samples were divided to give three biological replicates for uninfected and infected groups (each replicate containing pooled head tissue from six animals). The total RNA was extracted using TRI Reagent ${ }^{\circledR}$ (Ambion, UK) according to manufacturer's instructions and cleaned using RNA Clean and Concentrator ${ }^{\mathrm{TM}}-5$ columns (Zymo Research, Orange, CA, USA). The RNA quantity and quality was assessed using a spectrophotometer (NanoDrop 1000) and agarose-gel electrophoresis, respectively. From the extracted RNA, $250 \mathrm{ng}$ was reverse transcribed into cDNA using reverse transcriptase (Promega, UK) following the manufacturer's guidelines using OligoDT $\mathrm{T}_{15}$ primers and RNasin Ribonuclease Inhibitor (NEB, UK). The quality of the resulting cDNA was tested by PCR amplification of the constitutively expressed GAPDH gene as previously described (Yang et al. 2011).

\section{Q-PCR analysis}

SYBR green-based qPCR was performed using a real-time PCR cycler (Eco Illumina). Each reaction was performed in triplicate and the absence of genomic DNA was confirmed by performing minus reverse transcription (RT) reactions for all samples. Reactions were carried out using GoTaq qPCR Master Mix (Promega, UK) in a $15 \mu \mathrm{L}$ volume containing $1 \mu \mathrm{L}$ of $\mathrm{cDNA}, 0 \cdot 4 \mu \mathrm{L}$ of the forward and reverse primer taken from a $10 \mu \mathrm{M}$ stock (note: $0 \cdot 2 \mu \mathrm{L}$ of forward and reverse primer was used for ine1, 2 and $5-H T_{1 A}$ genes), $5 \cdot 7 \mu \mathrm{L}$ ultra-pure water and $7 \cdot 5 \mu \mathrm{L}$ of $2 \mathrm{X}$ GoTaq qPCR Master Mix. Reactions were carried out with Rox normalization and underwent an initial incubation step of $95^{\circ} \mathrm{C}$ for $2 \mathrm{~min}$, followed by 40 cycles of $95^{\circ} \mathrm{C}$ for $15 \mathrm{~s}$ and $60^{\circ} \mathrm{C}$ for $60 \mathrm{~s}$, completed with 1 cycle of $60^{\circ} \mathrm{C}$ for $95 \mathrm{~s}$. Melt curve analysis was performed to confirm the specificity of the PCR product in each reaction. The amplification data were analysed by plotting the fluorescence signal $\Delta \mathrm{Rn}$
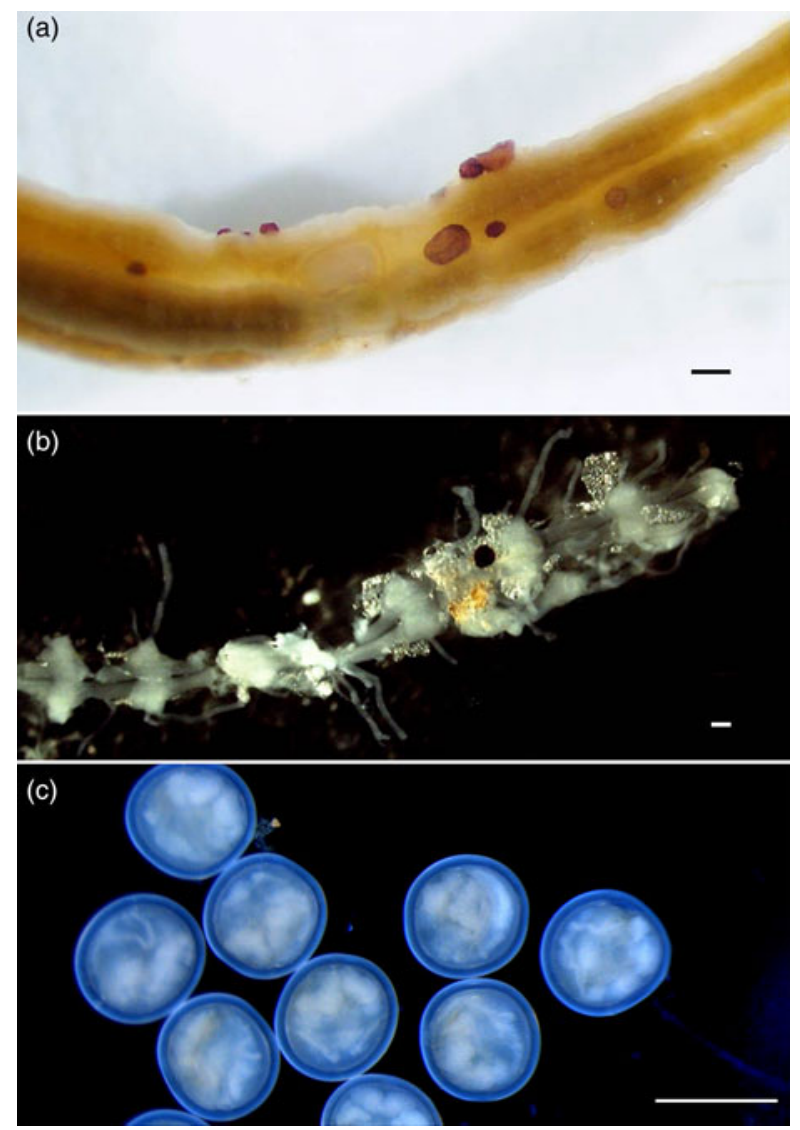

Fig. 1. Metacercariae of trematodes that have encysted and melanized in the (a) hepatopancreas (scale bar $=200$ $\mu \mathrm{M})$ and (b) ventral nerve cord of Echinogammarus marinus (scale bar $=100 \mu \mathrm{M}$ ) and (c) unmelanized metacariae from E. marinus body cavity (scale bar $=400 \mu \mathrm{M}$ ).

against the cycle number. An arbitrary threshold was selected within the linear phase of the $\log \Delta R n$ against cycle number plot. The quantification cycle (Cq value) was determined to be the cycle number at which $\Delta \mathrm{Rn}$ crossed this threshold. A relative expression of a gene was determined using the $\Delta \Delta \mathrm{Cq}$ method, with normalization to the expression of the GAPDH reference gene, using the dedicated Eco (v3·0) software package. Statistical differences in the expression of infected $v s$ unifected samples were compared using an independent $t$-test $(\alpha 0 \cdot 05)$.

RESULTS

\section{Trematode characterization and identification}

The parasite residing in E. marinus was found to encyst within the brain, hepatopancreas and abdomen, as well being attached to nerves in the thorax (Fig. 1). A survey of infection prevalence and intensity in 120 specimens during June and July 2011 revealed that approximately half the population were infected by one or more encysted trematodes $(55 \cdot 7 \%$ males and $50 \cdot 7 \%$ females $)$. The mean intensity $(9 \cdot 8)$ and abundance $(4 \cdot 9)$ of infection was greater for females than for males $(4 \cdot 8$ and $2 \cdot 7$, 


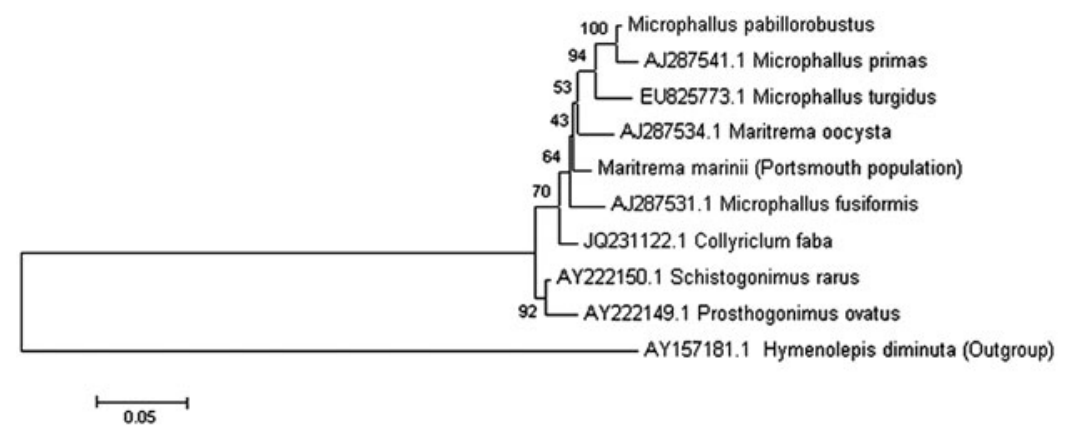

Fig. 2. Identification of unknown trematode species infecting Echinogammarus marinus at Langstone Harbour, UK. Molecular characterization of the well-studied trematode Microphallus pabillorobustus. A representative phylogenetic tree was generated using available rDNA sequences of digenean trematodes from NCBI. Sequences were aligned using MUSCLE and a phylogenetic tree was constructed using the maximum likelihood method implemented by the MEGA (Version 5) program. Bootstrap values $(n=100)$ for branches are shown as percentages. All branches are drawn to scale as indicated by the scale bar representing sequence divergence. The phylogenetic tree was generated as described above using trematode small subunit rDNA sequences $(18 \mathrm{~S})$; scale bar represents $5 \%$ sequence divergence.

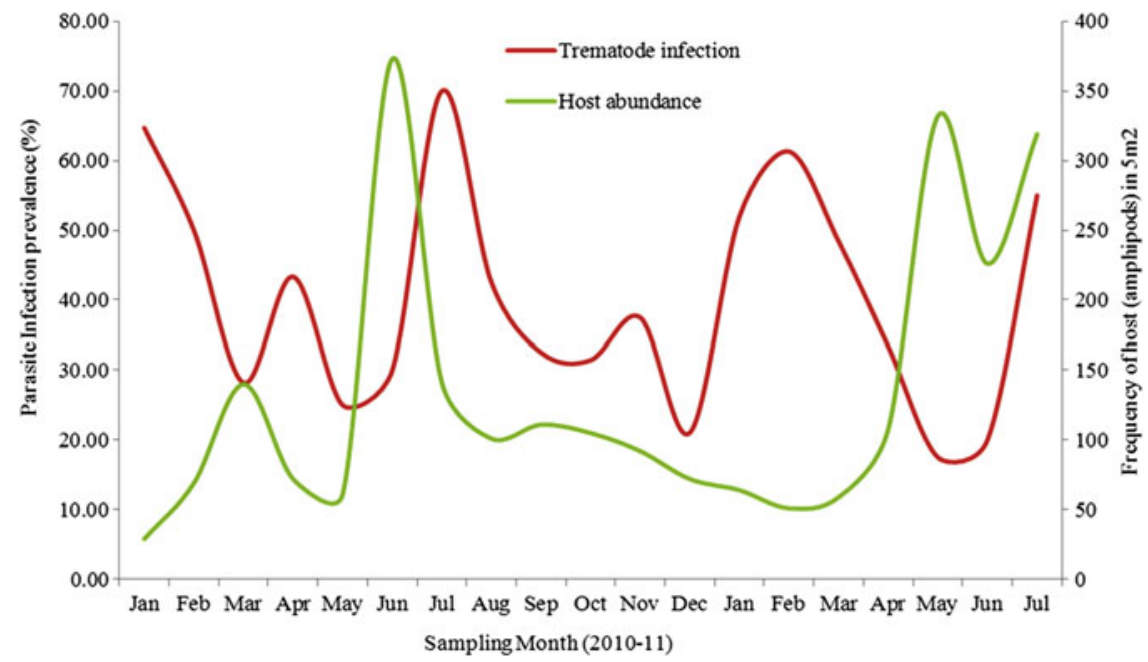

Fig. 3. Overall monthly infections prevalence of trematode sp. infecting Echinogammarus marinus population at Langstone Harbour (Portsmouth, UK) between January 2010 and July 2011.

respectively). Those that were found infecting the brain were found to make up approximately 7-9\% of the total population $(\sim 20 \%$ of the infected portion) with similar infection between males and females The $18 \mathrm{~S}, 28 \mathrm{~S}$ and ITS regions of the parasite ribosomal RNA gene was obtained and used in conjunction with previously published sequences to perform a phylogenetic analysis. This reveals that the unknown parasite within the E. marinus population at Langstone Harbour is a trematode belonging to the family Microphallidae (Fig. 2). On the basis of rRNA gene sequence comparisons, the $E$. marinus parasite represents a new species of trematode falling between the branches of the genus Maritrema and Microphallus (Tkach et al. 2003).

\section{Determination of trematode seasonal prevalence}

To assess whether the trematode infecting $E$. marinus may cause population level effects, an 18- month field study (January 2010-June 2011) was undertaken to determine if parasite prevalence significantly correlates with host abundance. The overall mean infection prevalence over the study period was $40 \cdot 2 \pm 3 \cdot 6 \%$ and ranged from $17 \cdot 5$ to $70 \cdot 0 \%$. Infection prevalence peaked in February and July for both 2010 and 2011, with a crash in infection rates in October 2010 (Fig. 3). There was no correlation observed between the trematode prevalence and host abundance when directly comparing the months (Pearson's correlation coefficient; $R=$ $-0 \cdot 330, P=0 \cdot 168)$. However, as trematode prevalence can have a delayed effect on host abundance (due to the time required to produce a development stage capable of definitive host infection), the trematode prevalence was aligned +1 month. This adjustment resulted in a significant negative relationship between host abundance and parasite prevalence (Pearson's correlation coefficient; $R=-0 \cdot 461, P=$ $0 \cdot 047$ ) (Fig. 4). Regression analysis failed to detect 


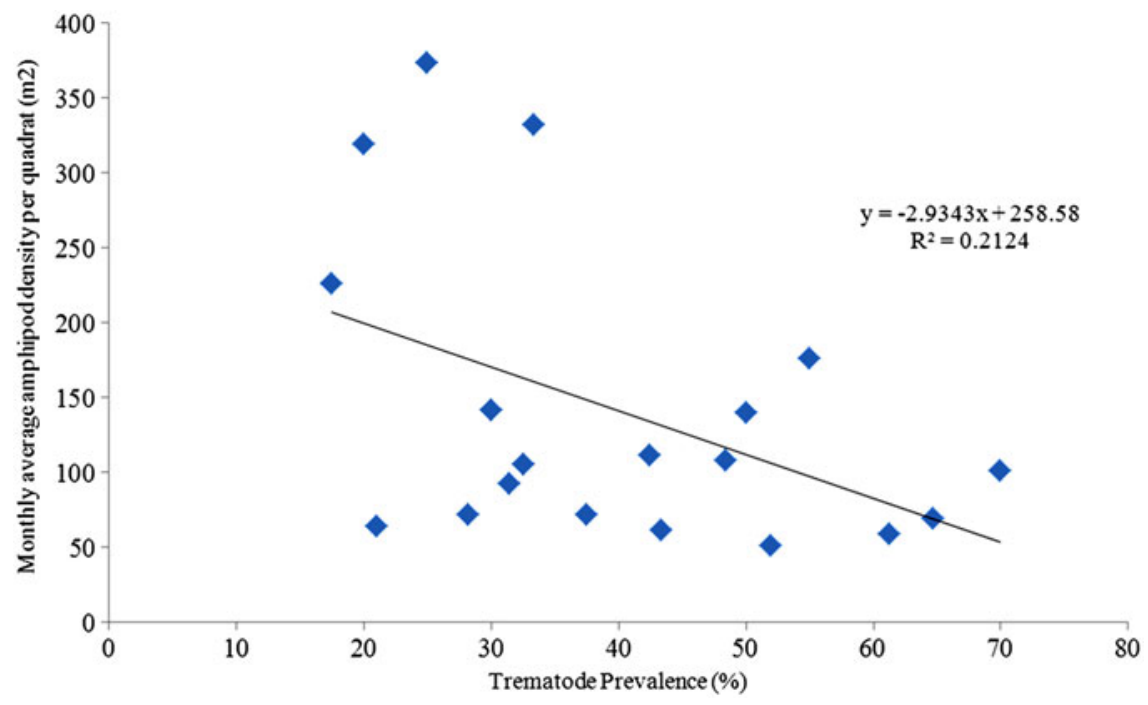

Fig. 4. Linear relationship between Echinogammarus marinus density from Langstone Harbour, Portsmouth (UK) and prevalence of a trematode parasite. Data obtained from field study during 2009-2011.

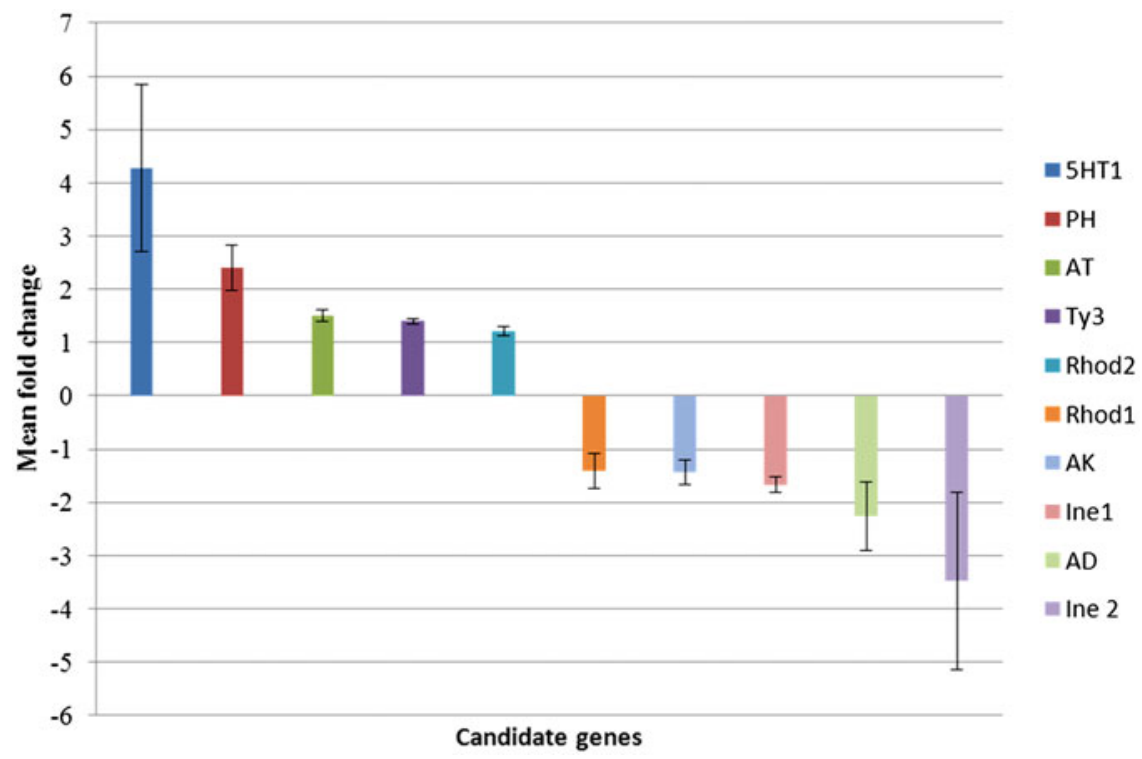

Fig. 5. Gene expression changes in Echinogammarus marinus induced by trematode infection in three independent trials with a mean and standard error ( \pm 1 s.E.). qPCR analysis of possible serotonin related genes using $E$. marinus head cDNA pooled $(n=6)$ control (uninfected) and infected trematode for each trial. Abbreviation: qPCR, quantitative real-time polymerase chain reaction. Bars represent mean fold change and error bars \pm 1 s.e.

a relationship between trematode prevalence and environmental parameters such as sea temperature $(P$ $=0 \cdot 135, R=0 \cdot 582, \mathrm{df}=1, F=0 \cdot 315)$ or salinity $(P$ $=0 \cdot 282, R=0 \cdot 260, \mathrm{df}=1, F=1 \cdot 236)$.

\section{Gene expression analysis}

Following candidate gene selection, ten sequences, representing genes with plausible links to neuronal pathways (Table 2), were chosen from the $E$. marinus transcriptome (Short et al. 2014) for expression analysis in infected and uninfected animals. Three biologically independent repeats indicated several genes present altered expression in infected animals (Fig. 5; Table 3). The expression of putative Tryptophan 5-monooxygenase activation protein gene (Ty3), two putative Rhodopsin genes (Rhod 1 and Rhod 2), the putative amino acid nutrient transporter gene $(A T)$, the putative Arginine Kinase gene $(A K)$ and the inebriated-like neurotransmitter gene 1 (Ine1) present no altered expression in trematode infected E. marinus. However, the putative serotonin receptor gene $\left(5-H T_{1 A}\right)$ and tryptophan hydroxylase gene $(P H)$ present consistently increased expression in infected animals in each biologically independent trial, with $5-H T_{1 A}$ showing the highest overall mean fold change. In contrast, the inebriated-like neurotransmitter gene 2 (Ine2) and the putative amino 
Table 3. Fold change in expression of putative neurological genes in trematode infected normalized Echinogammarus marinus to uninfected individuals

\begin{tabular}{|c|c|c|c|c|c|}
\hline Trial & 1 & 2 & 3 & Mean & s.E. \\
\hline 5HT1 & $7 \cdot 362$ & $3 \cdot 135$ & $2 \cdot 297$ & $4 \cdot 265$ & $1 \cdot 567$ \\
\hline $\mathrm{PH}$ & $2 \cdot 042$ & $3 \cdot 249$ & 1.932 & $2 \cdot 408$ & $0 \cdot 422$ \\
\hline $\mathrm{AT}$ & $1 \cdot 301$ & $1 \cdot 683$ & $1 \cdot 537$ & $1 \cdot 507$ & $0 \cdot 111$ \\
\hline Ту3 & $1 \cdot 292$ & $1 \cdot 414$ & $1 \cdot 485$ & $1 \cdot 397$ & $0 \cdot 056$ \\
\hline Rhod2 & $1 \cdot 301$ & $1 \cdot 277$ & $1 \cdot 050$ & $1 \cdot 209$ & $0 \cdot 080$ \\
\hline Rhod1 & $-2 \cdot 085$ & $-1 \cdot 094$ & $-1 \cdot 050$ & $-1 \cdot 409$ & $0 \cdot 338$ \\
\hline $\mathrm{AK}$ & $-1 \cdot 190$ & $-1 \cdot 214$ & $-1 \cdot 892$ & $-1 \cdot 432$ & $0 \cdot 230$ \\
\hline Ine1 & $-1 \cdot 434$ & $-1 \cdot 611$ & -1.953 & $-1 \cdot 666$ & $0 \cdot 152$ \\
\hline $\mathrm{AD}$ & $-3 \cdot 387$ & $-2 \cdot 204$ & $-1 \cdot 182$ & $-2 \cdot 258$ & $0 \cdot 637$ \\
\hline Ine 2 & $-6 \cdot 727$ & $-2 \cdot 477$ & $-1 \cdot 223$ & $-3 \cdot 475$ & $1 \cdot 666$ \\
\hline
\end{tabular}

$\mathrm{AD}$, acid decarboxylase gene; AK, Arginine Kinase gene; AT, acid nutrient transporter gene; Ine1 and Ine 2, inebriatedlike neurotransmitter gene 1 and 2; Ty3, tryptophan 5-monooxygenase activation protein gene; Rhod2 and Rhod1, two putative Rhodopsin genes; $\mathrm{PH}$, tryptophan hydroxylase gene; 5HT1, 5-hydroxytryptamine.

acid decarboxylase gene $(A D)$ present reduced expression in infected animals. For the two genes that present the greatest overall fold change in infected animals $\left(5-H T_{1 A}\right.$ and Ine2), the greatest change in expression was observed in experimental repeat 1 (Fig. 5). Despite some consistency in the up or downregulation of genes, no significant differences were observed in the mean expression values between infected and uninfected samples $(P>0 \cdot 05)$.

\section{DISCUSSION}

Parasites account for a substantial portion of an ecosystem's total biomass (Kuris et al. 2008) and play pivotal roles in community structures and ecosystem dynamics (Holmes, 1996; Horwitz and Wilcox, 2005; Hudson et al. 2006; Wood et al. 2007; Lefevre et al. 2009). Parasites that are capable of manipulating their host's behaviour to enhance transmission are of particular interest to both ecologists and parasitologists (Poulin and Mouritsen, 2006; Lefevre et al. 2009). This study investigates one such parasite infecting a population of the amphipod E. marinus. The rRNA gene subunit sequences revealed the parasite to be a trematode within the Microphallidae family. Our findings suggest this newly described species can dramatically influence its E. marinus host population. The parasite prevalence reached almost $70 \%$ at some points of the year and was found to significantly correlate with host abundance in a negative fashion. It is thought that populations of Corophium amphipods infected with trematodes are prone to local collapse due to the capacity of its parasites to induce behavioural change (Damsgaard et al. 2005), and our findings are certainly consistent with the hypothesis that trematodes can have a major impact on amphipod populations. In addition, we found no significant relationship between trematode abundance and any recorded environmental parameter, a finding also consistent with other trematode and host population studies
(Lagrue and Poulin, 2008). The large fluctuations in the prevalence of trematode infection possibly reflect a build-up of individuals infected with trematode cysts undergoing a period of development prior to reaching the infective stage, after which the parasite manipulates its host in an attempt to complete its life cycle. If successful, this manipulative strategy would cause an increase in mortality biased towards infected individuals, leading to a reduced prevalence of infection within the population. This scenario is consistent with the observed infection fluctuations in E. marinus. Further investigation is needed to determine the extent to which mortality results from increased predation facilitated by behavioural manipulation or the pathogenic effects of infection. However, mortality as a result of increased predation is in congruence with laboratory experiments revealing this parasite has the capacity to significantly influence $E$. marinus behaviour (Guler and Ford, 2010). In combination with other studies, our findings emphasize the potential importance of a parasite to the population dynamics of its host (Poulin and Mouritsen, 2006).

This study attempts to link the altered E. marinus behaviour observed in infected individuals (Guler and Ford, 2010) with the altered expression of genes with putative neurological functions. The majority of metacercariae were not found in the head region, but heavily encysted and melanized throughout the body cavity, including the hepatopancreas and encysting the ventral nerve cord. Whether this parasite can influence host behaviour from elsewhere in the hosts body (i.e. not within the head) is an interesting avenue to pursue especially given the production of serotonin throughout the ventral nerve cord (Harzsch and Waloszek, 2000) The 'neurological' sequences retrieved from the $E$. marinus transcriptome (Short et al. 2014) were annotated by comparison with publicly available gene sequences possessing varying levels of functional annotation. The evolutionary divergence between E. marinus and other arthropod species with well- 
annotated genomes means the extent of functional overlap between orthologous genes is uncertain. However, the degree of sequence similarity suggests that, even if some functional divergence has occurred, the E. marinus sequences likely represent genes with closely related neurological roles.

Several putative neurological genes were consistently up or downregulated across the three biologically independent repeats (e.g. putative $5-H T_{1 A}$ and Ine2, respectively) but with a notable extent of variation between the biological repeats. This variation may be due to several factors. Previously it has been shown that parasite load (Thomas and Poulin, 1998), age and size of parasite (Benesh et al. 2008), age of host (Poulin, 1993), infection by multiple parasite species (Cezilly et al. 2000; Haine et al. 2005) and seasonality (Brodeur and McNeil, 1989) can all affect the intensity of parasitic manipulation. In addition, these genes can be putatively linked to serotonin pathways. Serotonin is critical to many biological processes in invertebrates, including feeding, metabolism, moulting and reproduction (Yeoman et al. 1994; Fong, 1998, 2001), and the variation may reflect the involvement of these other processes. Overall, despite the variation, there is broad consistency in gene expression patterns between repeats, suggesting we have revealed the reliable alteration of 'neurological' gene expression associated with infection of $M$. marinnii. Of course, even assuming the chosen sequences represent genes critical to the regulation of host behaviour, it would still be uncertain whether the extent of altered regulation (e.g. $\sim 4$-fold in the case of $5-H T_{1 A}$ ) is sufficient to induce the observed behavioural changes (Guler and Ford, 2010). However, it is known that subtle differences in gene expression can lead to substantial neurological dysfunction (Tudor et al. 2002) and therefore the observed expression changes in $E$. marinus may, to some extent, account for the observed behavioural phenotype.

A trend in the expression of several genes with putative links to the serotonin pathway was found in infected $E$. marinus. In all three repeats, the gene encoding a putative $5-H T_{1 A}$ receptor gene and a tryptophan hydroxylase gene $(P H)$ was upregulated in the infected groups. The $5-\mathrm{HT}_{1 \mathrm{~A}}$ receptor is a transmembrane, G-protein coupled, somatodendritic autoreceptor within the dorsal raphe neurons and mediates inhibitory neurotransmission (Hall and Wedel, 1985). The activation of serotonin 1A receptors blocks subsequent serotonin release at the axon terminal, therefore significantly influences serotonin regulation in the brain ( $\mathrm{Riad}$ et al. 2000). Interestingly, the $5-\mathrm{HT}_{1 \mathrm{~A}}$ receptor is believed to play a pivotal role in desensitization following chronic administration of SSRIs and restraints serotonin elevation (Hjorth et al. 2000). This raises the hypothesis that the increased expression of this gene is an attempt by the host to counter balance the chronic elevation of serotonin induced by parasite infection. The $5-\mathrm{HT}_{1 \mathrm{~A}}$ receptor represents just a single receptor 5-HT subtype. Therefore, it would be of interest, given that various subtypes play different roles in modulating serotonin levels (Hjorth et al. 2000), to investigate the expression patterns of a larger range of receptor subtypes once a more complete $E$. marinus genomic resource is available. Such investigations have been attempted in the amphipod Gammarus pulex and suggest the $5-\mathrm{HT}_{2}$ receptor plays an important role in photic behaviour. In addition, the same study linked the histaminergic system with behavioural modulation, revealing the molecular interactions may be more complex than originally believed and suggesting potential future directions of study (Perrot-Minnot et al. 2013). Tryptophan hydroxylase $(P H)$ is a rate-limiting enzyme that catalyses serotonin biosynthesis in the serotonergic nerves (Kim et al. 2002). Therefore, the upregulation of this gene could potentially increase the biosynthesis of serotonin within the host brain. This hypothesis is supported by studies that have shown upregulation of a tryptophan hydroxylase gene in rats exposed to SSRIs (Kim et al. 2002; Shishkina et al. 2007). A recent study that measured gene expression in $E$. marinus exposed to the SSRIs sertraline and fluoxetine found no significant change in the expression of PH (Bossus et al. 2014), however, gene expression levels were measured following an 8 day exposure and infecting trematode parasites have considerably longer to modulate their hosts' gene expression. Furthermore, we do not currently have a detailed mechanistic understanding of the gene pathways influenced, it is possible that SSRIs and manipulating parasites influence serotonin related pathways in different ways and therefore cause distinct gene expression profiles. Whether the upregulation of the $5-H T_{1 A}$ gene expression is in response to elevated $\mathrm{PH}$ levels is unclear at this stage but is a plausible hypothesis.

A slight trend in downregulation of the putative amino acid decarboxylase $(A D)$ was observed in all experimental repeats. This was unexpected, as past work on gammarids infected with behaviour manipulating parasites have demonstrated increased expression of aromatic L-amino acid decarboxylase proteins (Kostadinova and Mavrodieva, 2005). Although, it should also be noted that the differential expression of aromatic L-amino acid decarboxylase was shown in gammarid species that display only altered phototaxis (Kostadinova and Mavrodieva, 2005), rather than combined phototaxic and geotaxic behavioural responses (Guler and Ford, 2010). However, as this study also finds upregulation of a putative tryptophan hydroxylase $(P H)$, the downregulation, albeit small, of the $A D$ gene is somewhat incongruous, as both enzymes are involved in serotonin synthesis, and requires further investigation. 
A study investigating the proteomic response of amphipod hosts to infection by behaviour manipulating parasites revealed that Arginine Kinase is induced in infected animals (Ponton et al. 2006). However, our study found no altered expression of the putative Arginine Kinase gene in trematode infected E. marinus. This difference may reflect divergent molecular strategies employed by various parasite species or a differential response by different host species. Of course, as our study measured mRNA levels, it is also possible that Arginine Kinase is post-transcriptionally regulated, leading to changes in proteins levels in infected animals that are not reflected by changes to transcript abundance.

The putative E. marinus inebriated-like neurotransmitter gene 2 (Ine2) presented consistent trend in downregulation in infected groups. Ine 2 is a neurotransmitter in Drosophila that resembles $\mathrm{Na}^{+} / \mathrm{Cl}^{-}$-dependent neurotransmitters, a family of transporters responsible for catalysing the rapid reuptake and release of neurotransmitters, such as serotonin, dopamine and norepinephrine, into the synapse (Soehnge et al. 1996). These neurotransmitters appear to play important roles in regulating behaviour. Dopamine deficiency in Drosophila can lead to several changes in behavioural traits including phototaxis, activity levels, negative geotaxis and olfactory learning (Riemensperger et al. 2011). It has also been shown that inebriated mutants present defective reuptake of neurotransmitters causing over stimulation of motor neurons and oscillations of the light-induced photoreceptor potential (Huang et al. 2002). The extent to which the Drosophila and putative E. marinus inebriated genes share a function is uncertain, however, given the sequence similarity, it is likely the putative E. marinus Ine 2 represents a closely related neurotransmitter. Although considerable work is required to better understand the function of this gene in E. marinus, it is plausible that its downregulation could lead to elevated neurotransmitter levels that could conceivably be associated with the behavioural traits observed in infected individuals.

New technologies applied to the study of animal behaviour are revealing links between the underlying genome and behavioural phenotypes (Bell and Robinson, 2011). Such investigations will elucidate the genetic basis of novel behaviours and help answer important evolutionary questions about the life histories of parasites and their hosts. Furthermore, a better understanding of the pathways from genes to phenotypes will increase our knowledge of the mechanistic basis of animal behaviour. Amphipods clearly represent one of the best animal groups for the study of parasiteinduced behavioural manipulation (Bethel and Holmes, 1973; Helluy, 1983a, b, 2013; Helluy and Holmes, 1990; Cezilly et al. 2000; Helluy and
Thomas, 2003; Damsgaard et al. 2005; Kostadinova and Mavrodieva, 2005; Ponton et al. 2005, 2006; Leung and Poulin, 2006; Tain et al. 2007). However, in comparison with well-established model arthropod species, investigations using amphipods have been hampered by a lack of genomic resources and an inability to apply transgenic technologies. However, the progress currently being made in both areas (Rehm et al. 2009; Zeng et al. 2011; Hook et al. 2013; Christie, 2014; Short et al. 2014) will greatly facilitate research uncovering the molecular biology underlying parasite-induced behavioural manipulation.

In summary, this study found the seasonal prevalence of a newly identified species of parasite infecting an amphipod population significantly correlated with host abundance in a negative fashion. When taken together with behavioural assays (Guler and Ford, 2010) and the observed transcriptomic alterations, our findings are consistent with the hypothesis that this trematode species can alter the behaviour of its host by modulating neuronal processes, and this influence increases the likelihood of predation to the extent of causing population level effects. These findings add to the mounting evidence that parasites alter their host's behaviour in ways that promote transmission and represent some of the first links between parasite-induced behavioural manipulation of amphipods and changes in gene expression. Although the data we present here are clearly of a preliminary nature, this study has produced a foundation for a deeper understanding of the consequences of trematode infection the amphipod E. marinus.

\section{ACKNOWLEDGEMENTS}

We are very appreciative to Dr Frédéric Thomas for kindly donating $G$. insensibilis infected by $M$. pabillorobustus.

\section{FINANCIAL SUPPORT}

Y. G and S. S are supported by the Natural Environment Research Council (UK) grant (NE/G004587/1) awarded to $\mathrm{P}$. $\mathrm{K}$ and $\mathrm{A}$. T. F.

\section{REFERENCES}

Adamo, S. A. (2013). Parasites: evolution's neurobiologists. Fournal of Experimental Biology 216, 3-10.

Bell, A. and Robinson, G. (2011). Behavior and the dynamic genome. Science 332, 1161-1162.

Benesh, D.P., Valtonen, E. T. and Seppaelae, O. (2008). Multidimensionality and intra-individual variation in host manipulation by an acanthocephalan. Parasitology 135, 617-626.

Bethel, W. M. and Holmes, J. C. (1973). Altered evasive behavior and responses to light in amphipods harboring acanthocephalan cystacanths. fournal of Parasitology 59, 945-956.

Biron, D. G. and Loxdale, H. D. (2013). Host-parasite molecular crosstalk during the manipulative process of a host by its parasite. Fournal of Experimental Biology 216, 148-160.

Bossus, M. C., Guler, Y. Z., Short, S. J., Morrison, E. R. and Ford, A. T. (2014). Behavioural and transcriptional changes in the amphipod 
Echinogammarus marinus exposed to two antidepressants, fluoxetine and sertraline. Aquatic Toxicology 151, 46-56.

Brodeur, J. and McNeil, J. N. (1989). Seasonal microhabitat selection by an endoparasitoid through adaptive modification of host behavior. Science 244, 226-228.

Camp, J. W. and Huizinga, H. W. (1979). Altered color, behavior and predation susceptibility of the isopod Asellus intermedius infected with acanthocephalus-dirus. Fournal of Parasitology 65, 667-669.

Cezilly, F., Gregoire, A. and Bertin, A. (2000). Conflict between cooccurring manipulative parasites? An experimental study of the joint influence of two acanthocephalan parasites on the behaviour of Gammarus pulex. Parasitology 120, 625-630.

Christie, A. E. (2014). Identification of the first neuropeptides from the Amphipoda (Arthropoda, Crustacea). General and Comparative Endocrinology 206, 96-110.

Combes, C. (1991). Ethological aspects of parasite transmission. American Naturalist 138, 866-880.

Combes, C., Fournier, A., Mone, H. and Theron, A. (1994). Behaviors in trematode cercariae that enhance parasite transmission: patterns and processes. Parasitology 109, S3-S13.

Damsgaard, J. T., Mouritsen, K. N. and Jensen, K. T. (2005). Surface activity of Corophium volutator: a role for parasites? Fournal of Sea Research 54, 176-184.

Esch, G. W., Barger, M. A. and Fellis, K. J. (2002). The transmission of digenetic trematodes: style, elegance, complexity. Integrative and Comparative Biology 42, 304-312.

Fong, P.P. (1998). Zebra mussel spawning is induced in low concentrations of putative serotonin reuptake inhibitors. Biological Bulletin 194, 143-149.

Fong, P. P. (2001). Antidepressants in aquatic organisms: a wide range of effects. In Pharmaceuticals and Care Products in the Environment (ed. Daughton, C. G. and Jones-Lepp, T. L.), pp. 264-281. American Chemical Society, Washington, DC, USA.

Guler, Y. and Ford, A. (2010). Anti-depressants make amphipods see the light. Aquatic Toxicology 99, 397-404.

Haas, W. (1994). Physiological analyses of host-finding behavior in trematode cercariae: adaptations for transmission success. Parasitology 109, S15-S29.

Haine, E. R., Boucansaud, K. and Rigaud, T. (2005). Conflict between parasites with different transmission strategies infecting an amphipod host. Proceedings of the Royal Society B: Biological Sciences 272, 2505-2510.

Hall, B. G. (2013). Building phylogenetic trees from molecular data with MEGA. Molecular Biology and Evolution 30, 1229-1235.

Hall, H. and Wedel, I. (1985). The effects of manipulation of presynaptic 5 -HT nerve terminals on postsynaptic 5-HT1 and 5-HT2 binding sites of the rat brain. Fournal of Neural Transmission 64, 129-143.

Harzsch, S. and Waloszek, D. (2000). Serotonin-immunoreactive neurons in the ventral nerve cord of Crustacea: a character to study aspects of arthropod phylogeny. Arthropod Structure and Development 29, 307-322.

Helluy, S. (1983a). A process favoring parasite transmission: the manipulation of intermediate host behavior. Revue d'Ecologie La Terre et la Vie 38, 211-223.

Helluy, S. (1983b). Relations hôtes-parasite du trématode Microphallus papillorobustus (Rankin, 1940). II. Modifications du comportement des Gammarus hôtes intermédiaires et localisation des métacercaires. Annales De Parasitologie Humaine Et Comparee 58, 1-17.

Helluy, S. (2013). Parasite-induced alterations of sensorimotor pathways in gammarids: collateral damage of neuroinflammation? Fournal of Experimental Biology 216, 67-77.

Helluy, S. and Holmes, J. C. (1990). Serotonin, octopamine, and the clinging behavior induced by the parasite Polymorphus paradoxus (Acanthocephala) in Gammarus lacustris (Crustacea). Canadian fournal of Zoology 68, 1214-1220.

Helluy, S. and Thomas, F. (2003). Effects of Microphallus papillorobustus (Platyhelminthes: Trematoda) on serotonergic immunoreactivity and neuronal architecture in the brain of Gammarus insensibilis (Crustacea Amphipoda). Proceedings of the Royal Society B:Biological Sciences 270, $563-568$.

Helluy, S. and Thomas, F. (2010). Parasitic manipulation and neuroinflammation: evidence from the system Microphallus papillorobustus (Trematoda)-Gammarus (Crustacea). Parasites and Vectors 3, 38

Hjorth, S., Bengtsson, H. J., Kullberg, A., Carlzon, D., Peilot, H. and Auerbach, S. B. (2000). Serotonin autoreceptor function and antidepressant drug action. Fournal of Psychopharmacology 14, 177-185.

Holmes, J. C. (1996). Parasites as threats to biodiversity in shrinking ecosystems. Biodiversity and Conservation 5, 975-983.

Hook, S.E., Twine, N.A., Simpson, S.L., Spadaro, D. A., Moncuquet, P. and Wilkins, M.R. (2013). 454 pyrosequencing-based analysis of gene expression profiles in the amphipod Melita plumulosa: transcriptome assembly and toxicant induced changes. Aquatic Toxicology 153, 73-88.

Horwitz, P. and Wilcox, B. A. (2005). Parasites, ecosystems and sustainability: an ecological and complex systems perspective. International fournal for Parasitology 35, 725-732.

Huang, X., Huang, Y. M., Chinnappan, R., Bocchini, C., Gustin, M. C. and Stern, M. (2002). The Drosophila inebriated-encoded neurotransmitter/osmolyte transporter: dual roles in the control of neuronal excitability and the osmotic stress response. Genetics 160, 561-569.

Hudson, P. J., Dobson, A. P. and Lafferty, K. D. (2006). Is a healthy ecosystem one that is rich in parasites? Trends in Ecology and Evolution 21, 381-385.

Kim, S. W., Park, S. Y. and Hwang, O. (2002). Up-regulation of tryptophan hydroxylase expression and serotonin synthesis by sertraline. Molecular Pharmacology 61, 778-785.

Klein, S. L. (2003). Parasite manipulation of the proximate mechanisms that mediate social behavior in vertebrates. Physiology and Behavior $\mathbf{7 9}$, 441-449.

Kostadinova, A. and Mavrodieva, R. S. (2005). Microphallids in Gammarus insensibilis Stock, 1966 from a Black Sea lagoon: host response to infection. Parasitology 131, 347-354.

Kuris, A. M., Hechinger, R. F., Shaw, J. C., Whitney, K. L., AguirreMacedo, L., Boch, C. A., Dobson, A.P., Dunham, E. J., Fredensborg, B. L., Huspeni, T. C., Lorda, J., Mababa, L., Mancini, F. T., Mora, A.B., Pickering, M., Talhouk, N. L., Torchin, M. E. and Lafferty, K. D. (2008). Ecosystem energetic implications of parasite and free-living biomass in three estuaries. Nature 454, $515-518$.

Lagrue, C. and Poulin, R. (2008). Lack of seasonal variation in the lifehistory strategies of the trematode Coitocaecum parvum: no apparent environmental effect. Parasitology 135, 1243-1251.

Lefevre, T., Lebarbenchon, C., Gauthier-Clerc, M., Misse, D., Poulin, R. and Thomas, F. (2009). The ecological significance of manipulative parasites. Trends in Ecology and Evolution 24, 41-48.

Leung, T. L.F. and Poulin, R. (2006). Effects of the trematode Maritrema novaezealandensis on the behaviour of its amphipod host: adaptive or not? Yournal of Helminthology 80, 271-275.

Mouritsen, K. N. and Poulin, R. (2002). Parasitism, community structure and biodiversity in intertidal ecosystems. Parasitology 124, S101-S117.

Near, T. J., Garey, J. R. and Nadler, S. A. (1998). Phylogenetic relationships of the Acanthocephala inferred from $18 \mathrm{~S}$ ribosomal DNA sequences. Molecular Phylogenetics and Evolution 10, 287-298.

Nolan, T. J. (1998). Parasites and pathogens effects on host hormones and behavior. Parasitology Today 14, 209.

Olson, P.D., Cribb, T.H., Tkach, V.V., Bray, R.A. and Littlewood, D. T. J. (2003). Phylogeny and classification of the Digenea (Platyhelminthes: Trematoda). International fournal for Parasitology 33, 733-755.

Pearson, J. C. (1972). A phylogeny of life cycle patterns of the Digenea. Advances in Parasitology 10, 153-189.

Perrot-Minnot, M.-J., Dion, E. and Cézilly, F. (2013). Modulatory effects of the serotonergic and histaminergic systems on reaction to light in the crustacean Gammarus pulex. Neuropharmacology 75, 31-37.

Perrot-Minnot, M.-J., Sanchez-Thirion, K. and Cézilly, F. (2014). Multidimensionality in host manipulation mimicked by serotonin injection. Proceedings of the Royal Society B: Biological Sciences 281, 20141915. Ponton, F., Biron, D. G., Joly, C., Helluy, S., Duneau, D. and Thomas, F. (2005). Ecology of parasitically modified populations: a case study from a gammarid-trematode system. Marine Ecology-Progress Series 299, 205-215.

Ponton, F., Lefevre, T., Lebarbenchon, C., Thomas, F., Loxdale, H.D. Marche, L., Renault, L., Perrot-Minnot, M. J. and Biron, D. G. (2006). Do distantly related parasites rely on the same proximate factors to alter the behaviour of their hosts? Proceedings of the Royal Society B: Biological Sciences 273, 2869-2877.

Poulin, R. (1993). Age-dependent effects of parasites on antipredator responses in two New zealand fresh-water fish. Oecologia 96, 431-438.

Poulin, R. and Mouritsen, K. N. (2006). Climate change, parasitism and the structure of intertidal ecosystems. Fournal of Helminthology $\mathbf{8 0}$, 183-191.

Pryon, S. C. and Elizee, R. (2000). Evidence of opiates and opioid neuropeptides and their immune effects in parasitic invertebrates representing three different phyla: Schistosoma mansoni, Theromyzon tessulatum, Trichinella spiralis. Acta Biologica Hungarica 51, 331-341.

Rehm, E. J., Hannibal, R. L., Chaw, R.C., Vargas-Vila, M. A. and Patel, N. H. (2009). The crustacean Parhyale hawaiensis: a new model 
for arthropod development. Cold Spring Harbor Protocols, pdb.emo114pdb.emo114. doi: 10.1101/pdb.emo114

Riad, M., Garcia, S., Watkins, K. C., Jodoin, N., Doucet, E. Langlois, X., El Mestikawy, S., Hamon, M. and Descarries, L. (2000). Somatodendritic localization of 5-HT1A and preterminal axonal localization of 5-HT1B serotonin receptors in adult rat brain. Fournal of Comparative Neurology 417, 181-194.

Riemensperger, T., Isabel, G., Coulom, H., Neuser, K., Seugnet, L., Kume, K., Iché-Torres, M., Cassar, M. n., Strauss, R. and Preat, T. (2011). Behavioral consequences of dopamine deficiency in the Drosophila central nervous system. Proceedings of the National Academy of Sciences 108, 834-839.

Rozen, S. and Skaletsky, H. (2000). Primer3 on the www for general users and for biologist programmers. Methods in Molecular Biology 132 365-386.

Shaw, J. C., Korzan, W. J., Carpenter, R. E., Kuris, A. M., Lafferty, K. D., Summers, C. H. and Overli, O. (2009). Parasite manipulation of brain monoamines in California killifish (Fundulus parvipinnis) by the trematode Euhaplorchis californiensis. Proceedings of the Royal Society B Biological Sciences 276, 1137-1146.

Shishkina, G. T., Kalinina, T. S. and Dygalo, N. N. (2007). Up-regulation of tryptophan hydroxylase- 2 mRNA in the rat brain by chronic fluoxetine treatment correlates with its antidepressant effect. Neuroscience $\mathbf{1 5 0}$ 404-412.

Short, S., Guler, Y., Yang, G., Kille, P. and Ford, A. T. (2012). Paramyxean-microsporidian co-infection in amphipods: is the consensus that Microsporidia can feminise their hosts presumptive? International Fournal for Parasitology 42, 683-691.

Short, S., Yang, G., Guler, Y., Green Etxabe, A., Kille, P. and Ford, A (2014). Crustacean intersexuality is feminisation without de-masculinisation: implications for environmental toxicology. Environmental Science and Technology 48, 13520-13529.

Soehnge, H., Huang, X., Becker, M., Whitley, P., Conover, D. and Stern, M. (1996). A neurotransmitter transporter encoded by the Drosophila inebriated gene. Proceedings of the National Academy of Sciences of the United States of America 93, 13262-13267.
Tain, L., Perrot-Minnot, M.-J. and Cezilly, F. (2006). Altered host behaviour and brain serotonergic activity caused by acanthocephalans: evidence for specificity. Proceedings of the Royal Society B: Biological Sciences 273, 3039-3045.

Tain, L., Perrot-Minnot, M.-J. and Cézilly, F. (2007). Differential influence of Pomphorhynchus laevis (Acanthocephala) on brain serotonergic activity in two congeneric host species. Biology letters 3, 68-71.

Thomas, F. and Poulin, R. (1998). Manipulation of a mollusc by a trophically transmitted parasite: convergent evolution or phylogenetic inheritance? Parasitology 116, 431-436.

Thomas, F., Guegan, J. F., Michalakis, Y. and Renaud, F. (2000). Parasites and host life-history traits: implications for community ecology and species co-existence. International fournal for Parasitology 30, 669-674

Tkach, V. V., Littlewood, D. T. J., Olson, P.D., Kinsella, J. M. and Swiderski, Z. (2003). Molecular phylogenetic analysis of the Microphalloidea Ward, 1901 (Trematoda: Digenea). Systematic Parasitology 56, 1-15

Tudor, M., Akbarian, S., Chen, R.Z. and Jaenisch, R. (2002) Transcriptional profiling of a mouse model for Rett syndrome reveals subtle transcriptional changes in the brain. Proceedings of the National Academy of Sciences of the United States of America 99, 15536-15541.

Wood, C. L., Byers, J. E., Cottingham, K. L., Altman, I., Donahue, M. J. and Blakeslee, A.M.H. (2007). Parasites alter community structure. Proceedings of the National Academy of Sciences of the United States of America 104, 9335-9339.

Yang, G., Short, S., Kille, P. and Ford, A. T. (2011). Microsporidia infections in the amphipod, Echinogammarus marimus (Leach): suggestions of varying causal mechanisms to intersexuality. Marine Biology 158, 461-470. Yeoman, M. S., Kemenes, G., Benjamin, P. R. and Elliott, C. J. H (1994). Modulatory role for the serotonergic cerebral giant-cells in the feeding system of the snail, Lymnaea .II. Photoinactivation. Fournal of Neurophysiology 72, 1372-1382.

Zeng, V., Villanueva, K.E., Ewen-Campen, B.S., Alwes, F., Browne, W. E. and Extavour, C. G. (2011). De novo assembly and characterization of a maternal and developmental transcriptome for the emerging model crustacean Parhyale hawaiensis. BMC Genomics 12, 581. 